\title{
Bioefficacy of Entomopathogenic Nematodes against Spodoptera litura (Lepidoptera: Noctuidae) in Bhendi
}

\author{
Sharmila Radhakrishnan* and Subramanian Shanmugam
}

\author{
Department of Nematology, Tamil Nadu Agricultural University, \\ Coimbatore-641003, Tamil Nadu \\ *Corresponding author
}

\begin{tabular}{|c|c|}
\hline & A B S T R A C T \\
\hline Keywords & $\begin{array}{l}\text { The efficacy of entomopathogenic nematodes (EPN) against larvae of Spodoptera } \\
\text { litura (Lepidoptera: Noctuidae) in bhendi was evaluated under laboratory and }\end{array}$ \\
\hline $\begin{array}{l}\text { Entomopathogenic } \\
\text { nematodes, } \\
\text { Heterorhabditis } \\
\text { indica, Steinernema } \\
\text { glaseri, } \\
\text { Spodoptera litura, } \\
\text { Virulence, Bhendi. }\end{array}$ & 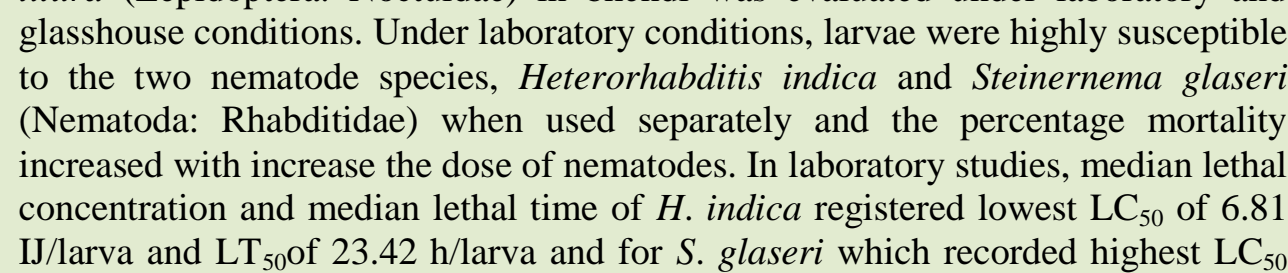 \\
\hline Article Info & $\begin{array}{l}8.45 \text { and } \mathrm{LT}_{50} \mathrm{of} 16.72 \mathrm{IJ} \text { /larva for } S \text {. litura. Median lethal time of } H \text {. indica was } \\
\text { less on } S \text {. litura than } S \text { glaseri under laboratorv conditions. Under pot culture }\end{array}$ \\
\hline $\begin{array}{l}\text { Accepted: } \\
\text { 21 June } 2017 \\
\text { Available Online: } \\
\text { 10 July } 2017\end{array}$ & $\begin{array}{l}\text { conditions larva of } H \text {. indica was more effective on } S \text {. litura than } S \text {. glaseri under } \\
\text { glasshouse conditions. The highest mortality of } 76.66 \text { per cent was observed with } \\
\text { H. indica } @ 5 \times 10^{9} \mathrm{IJ} / \text { ha with the least fruit damage of } 29.16 \text { per cent in bhendi. }\end{array}$ \\
\hline
\end{tabular}

\section{Introduction}

Spodoptera litura (Fabricius) (Lepidoptera: Noctuidae) is an obnoxious cosmopolitan pest that feeds on more than hundred host plants. This techniques have been used to combat this pest, among them chemical insecticides are well known for quick results but their serious harmful effects on the environment is also well documented.

The entomopathogenic nematodes of the genus Steinernema and Heterorhabditis (Rhabditida:

Steinernematidae, Heterorhabditidae) and their symbiotic bacteria are effective biological control agents of different insect pests. They persist in the soil as non-feeding, third stage infective juveniles (IJs) which seek, infect and kill susceptible insect hosts within 24-72h. Environmental concern over the consequences of use of chemical pesticides, especially residues in field, ground water contamination, wild life kills and development of insect resistance, pest resurgence and outbreak of secondary pests have compelled for intensive research for safe, eco-friendly alternative methods for insect management. The application of entomopathogenic nematodes in biological control was traditionally used to control soil pests until a few years ago. But the research 
from the last two decades indicates their marked potential against foliar pests under unique conditions. Earlier attempts have demonstrated that entomopathogenic nematodes at high concentrations, together with favourable abiotic components (high humidity and optimal temperature) can be highly effective biological control agents of insects in commercial agriculture (Laznik et al., 2012).

The aim of our present research was to study the efficacy of entomopathogenic nematodes against the Spodoptera litura to determine which species of EPN ( $H$. indica and $S$. glaseri) is the most effective as related to subtropical temperature and the nematode concentration. In the present study to investigated the efficacy of entomopathogenic nematode, $H$. indica and $S$. glaseri against larval stages of $S$. litura under laboratory and pot culture conditions.

\section{Materials and Methods}

\section{Insects rearing}

The rearing of our test insect, Spodoptera litura was done in laboratory on its natural diet, leaves of castor plant (Ricinuscom munis). Hundred eggs per day of ovulation were kept in separate sterilized jars and fresh surface sterilized castor leaves were provided for the first in star larvae on emergence. Cleaning, changing of food and thinning of the culture were done on regular basis to get healthy culture.

\section{Nematodes}

The nematodes viz., $H$. indica and $S$. glaseri were obtained from Sugarcane Breeding Institute, Coimbatore and mass cultured in $C$. cephlonica. The larvae were reared on broken cumbu grains sterilized at $100^{\circ} \mathrm{C}$ for 30 minutes, according to the procedure of Kaya and Gaugler (1993). The third stage juveniles
(IJs) were harvested from water surrounding White's trap within 10 days of emergence from their hosts. A stock suspension of the IJs in distilled water was stored at $20^{\circ} \mathrm{C}$ for 2 weeks before use in BOD incubator.

\section{Laboratory conditions}

Heterorhabditis indica and S. glaseri were used for testing virulence against S. litura. Dose and time mortality relationship tests were conducted in $9 \mathrm{~cm}$ diameter Petri dishes lined at the bottom with a Whatman No. 1 filter paper and moistened with $1 \mathrm{ml}$ sterile distilled water. Infective juveniles were evenly applied over the filter paper. The dosages used were $0,50,100,150,200$, 250 and 300 infective juveniles per larva, with 10 larvae of A. ipsilon per insect per replicate and four replicates for each level.

\section{Pot culture experiment}

Two pot culture experiments were carried out under glass house conditions for testing the bioefficacy of entomopathogenic nematodes against $S$. litura in Abelmoschuses culentus(cv. Parbhani Kranti). Seeds of bhendi were surface sterilized in 0.1 per cent mercuric chloride for a minute, washed in distilled water and the seeds @ 3 per pot, were sown in earthen pots of $5 \mathrm{~kg}$ capacity, containing pot mixture. After germination, the plants were thinned to four/pot. The plants were properly maintained with regular irrigation. After 40 days, plants reached the fruiting stage. Laboratory reared $4^{\text {th }}$ instar larvae of S. litura were collected and starved for about $3 \mathrm{~h}$ and fed with bhendi leaves to increase host suitability of larvae. The larvae were released on 40 day old plants at 4 per plant and the nematode treatments were given as $H$. indica@ $1.25,2.5$ and $5 \times 10^{9}$ $\mathrm{IJ} /$ ha and S. glaseri@ 1.25, 2.5 and $5 \times 10^{9}$ $\mathrm{IJ} / \mathrm{ha}$.

The treatments were replicated thrice in a Completely Randomized Design (CRD). 
Antidesicant, glycerine @ 0.1 per cent ( $1 \mathrm{ml} / 1)$ and UV protectant, Tween 20 @ 0.05 per cent $(0.5 \mathrm{ml} / 1)$ were added to the spray fluid $(25 \mathrm{ml} / \mathrm{pot})$ containing nematodes. Spraying of nematodes spray fluid was done at $1 \mathrm{~h}$ before sunset with a hand atomizer @ $25 \mathrm{ml} /$ plant. Insect mortality counts were taken every $24 \mathrm{~h}$ up to $72 \mathrm{~h}$ after spraying. The dead larvae were dissected in 0.1 per cent saline water and examined under microscope to confirm the death of larvae due to nematodes. Damaged leaves due to the larvae were also recorded in all the treatments.

\section{Statistical analysis}

The observations recorded were statistically analysed for the experiments. Means of all experiments were used to compare the efficacy of treatments. Per cent insect mortality data were analysed by multifactor ANOVA followed by Duncan's multiple range test $(\mathrm{P}>0.05)$ for separation of means.

\section{Results and Discussion}

\section{Laboratory experiment}

The virulence of two species of EPNs, viz., $H$. indica and $S$. glaseri were tested against larvae of $S$. litura under laboratory conditions. $H$. indica was more virulent to larvae of $S$. litura. The nematode $H$. indica caused lowest $\mathrm{LC}_{50}$ of $6.81 \mathrm{JJ} /$ larva and $\mathrm{LT}_{50}$ of 23.42 $\mathrm{h} /$ larva were observed for $S$. litura. The nematode species $S$.glaseri caused 50 per cent larval mortality of $S$. litura after $8.45 \mathrm{~h} /$ larva and 16.72 IJ/larva respectively, which consumed more time and high dose for causing maximum mortality period (Tables 1 and 2).

The virulence was determined in the present study by median lethal concentration $\left(\mathrm{LC}_{50}\right)$ and Median lethal time $\left(\mathrm{LT}_{50}\right)$ of $H$. indica and $S$. glaseri against insect pest of $S$. litura. The findings showed that $\mathrm{LC}_{50}$ and $\mathrm{LD}_{50}$ of $H$. indica was low for $S$. litura and high for S. glaseri. Umamaheswari et al., (2004) and Saravanapriya and Subramanian (2007) reported that $H$. indica as highly virulent against $S$. litura ( $\mathrm{LC}_{50}-3.5$ and $7 \mathrm{IJ} /$ larva) and caused 50 per cent mortality in a minimum time of $34.53 \mathrm{~h} /$ larva which confirm the present findings.

Divya et al., (2010) and King (1994) reported early instar larvae of $H$. armigera, S. litura and $G$. mellonella were more susceptible to $H$. indica, which confirm the present findings. The $\mathrm{LT}_{50}$ of $H$. indica to cause 50 per cent mortality of $S$. litura larvae in a minimum period was $23.42 \mathrm{~h} /$ larva. Similarly, Kalia et al., (2014) reported that the $\mathrm{LT}_{50}$ values of $S$. thermophilum were $41.40 \mathrm{~h}$ with $S$. litura and $33.6 \mathrm{~h}$ with $G$. mellonella.

\section{Pot culture experiment}

In pot culture experiment conducted under glass house conditions, $H$. indica and $S$. glaseri were found effective at all the dosages tested viz., $1.25 \times 10^{9}, 2.5 \times 10^{9}$ and $5 \times 10^{9} \mathrm{IJ} / \mathrm{ha}$. With respect to time, increased mortality was observed with increased exposure time after treatment.

At $24 \mathrm{~h}$ of exposure period, the highest larval mortality of 26.66 per cent was caused by $H$. indica@ $5 \times 10^{9} \mathrm{IJ} /$ ha followed by S. glaseri which caused a lowest larval mortality of 6.66 per cent @ $1.25 \times 10^{9} \mathrm{IJ} / \mathrm{ha}$. Similarly at $48 \mathrm{~h}$ of exposure period the same trend was observed for the two nematode species at different intervals. A larval mortality of 48.33 per cent was caused by $H$. indica @ $5 \times 10^{9}$ IJ/ha and 11.66 per cent of mortality was caused by $S$. glaseri at $1.25 \times 10^{9} \mathrm{IJ} / \mathrm{ha}$ respectively (Table 3 ). 
Table.1 LC50 Values calculated from dosage response assays conducted with different nematodes species and larvae of $S$. litura

\begin{tabular}{|l|c|c|c|c|}
\hline $\begin{array}{c}\text { Nematode } \\
\text { species }\end{array}$ & $\begin{array}{c}\text { Incubation } \\
\text { period (h) }\end{array}$ & LC $_{\mathbf{5 0}}$ & \multicolumn{2}{|c|}{ Fiducial limit (95 \%) } \\
\cline { 4 - 5 } & & & $\mathbf{U L}$ & $\mathbf{L L}$ \\
\hline H. indica & 24 & 8.41 & 6.23 & 8.23 \\
& 48 & 8.76 & 7.12 & 9.65 \\
& 72 & 6.81 & 4.98 & 9.32 \\
& 96 & 6.12 & 4.96 & 10.16 \\
\hline S. glaseri & 24 & 11.6 & 8.63 & 14.56 \\
& 48 & 10.89 & 7.89 & 13.41 \\
& 72 & 8.45 & 6.05 & 11.81 \\
& 96 & 7.23 & 5.42 & 6.87 \\
\hline
\end{tabular}

Table.2 LT50 Values calculated from dosage response assays conducted with different nematodes species and larvae of $S$. litura

\begin{tabular}{|l|c|c|c|c|}
\hline $\begin{array}{c}\text { Nematode } \\
\text { species }\end{array}$ & $\begin{array}{c}\text { Incubation } \\
\text { period (h) }\end{array}$ & LT $_{\mathbf{5 0}}$ & \multicolumn{2}{|c|}{ Fiducial limit (95 \%) } \\
\cline { 3 - 5 } & & & LL & UL \\
\hline H. indica & 24 & 25.34 & 21.54 & 23.45 \\
& 48 & 24.53 & 21.31 & 22.79 \\
& 72 & 23.42 & 19.98 & 27.44 \\
& 96 & 22.41 & 18.41 & 25.89 \\
\hline S. glaseri & 24 & 18.12 & 14.56 & 23.45 \\
& 48 & 17.56 & 14.23 & 22.89 \\
& 72 & 16.27 & 13.51 & 19.60 \\
& 96 & 15.89 & 12.56 & 18.23 \\
\hline
\end{tabular}

Table.3 Bioefficacy of entomopathogenic nematodes against larvae of S. litura on bhendi under pot culture conditions

\begin{tabular}{|c|c|c|c|c|}
\hline \multirow{2}{*}{ Treatments } & \multicolumn{3}{|c|}{ Per cent insect mortality (hr after treatment) } & \multirow{2}{*}{$\begin{array}{c}\text { Per cent } \\
\text { leaves } \\
\text { damage }\end{array}$} \\
\hline & 24 & 48 & 72 & \\
\hline 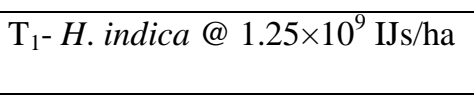 & $\begin{array}{c}6.66^{\mathrm{d}} \\
(14.75)\end{array}$ & $\begin{array}{l}18.33^{\mathrm{d}} \\
(25.30)\end{array}$ & $\begin{array}{c}60.00^{\mathrm{c}} \\
(50.79)\end{array}$ & $\begin{array}{l}58.33^{\mathrm{bc}} \\
(45.83)\end{array}$ \\
\hline $\mathrm{T}_{2}-H$. indica @ 2.5×10 $\mathrm{IJ} \mathrm{s} / \mathrm{ha}$ & $\begin{array}{c}16.66^{b} \\
(24.04)\end{array}$ & $\begin{array}{c}31.66^{\mathrm{c}} \\
(34.23)\end{array}$ & $\begin{array}{c}68.33^{b} \\
(55.77)\end{array}$ & $\begin{array}{c}45.83^{\mathrm{c}} \\
(42.58)\end{array}$ \\
\hline $\mathrm{T}_{3}-H$. indica @ $5 \times 10^{9} \mathrm{IJ} / \mathrm{ha}$ & $\begin{array}{l}26.66^{\mathrm{a}} \\
(31.07)\end{array}$ & $\begin{array}{l}48.33^{\mathrm{a}} \\
(44.04)\end{array}$ & $\begin{array}{c}76.66^{\mathrm{a}} \\
(61.14)\end{array}$ & $\begin{array}{l}29.16^{\text {bd }} \\
(32.58)\end{array}$ \\
\hline 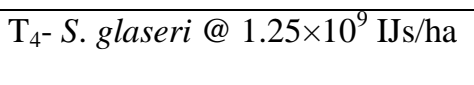 & $\begin{array}{c}6.66^{\mathrm{d}} \\
(14.75)\end{array}$ & $\begin{array}{c}11.66^{\mathrm{e}} \\
(19.88)\end{array}$ & $\begin{array}{l}31.66^{\mathrm{e}} \\
(34.23)\end{array}$ & $\begin{array}{c}66.66^{b} \\
(54.82)\end{array}$ \\
\hline $\mathrm{T}_{5^{-}}$S. glaseri @ 2.5 $\times 10^{9} \mathrm{IJ} \mathrm{s} / \mathrm{ha}$ & $\begin{array}{c}11.66^{\mathrm{C}} \\
(19.88)\end{array}$ & $\begin{array}{l}21.66^{\mathrm{c}} \\
(27.71)\end{array}$ & $\begin{array}{l}43.33^{\mathrm{d}} \\
(41.16)\end{array}$ & $\begin{array}{c}58.33^{\mathrm{c}} \\
(54.82)\end{array}$ \\
\hline 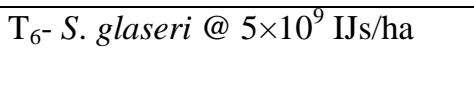 & $\begin{array}{l}21.66^{\mathrm{ab}} \\
(27.71)\end{array}$ & $\begin{array}{l}40.00^{d} \\
(39.21)\end{array}$ & $\begin{array}{c}66.66^{b} \\
(54.75)\end{array}$ & $\begin{array}{c}45.83^{\mathrm{c}} \\
(42.58)\end{array}$ \\
\hline $\mathrm{T}_{7^{-}}$Control & $\begin{array}{c}0 \\
(0.28)\end{array}$ & $\begin{array}{c}0 \\
(0.28)\end{array}$ & $\begin{array}{c}0 \\
(0.28)\end{array}$ & $\begin{array}{c}83.33^{\mathrm{a}} \\
(66.19)\end{array}$ \\
\hline $\mathrm{CD}(\mathrm{p}=0.05)$ & 4.11 & 3.59 & 3.28 & 7.79 \\
\hline
\end{tabular}


Subsequently at $72 \mathrm{~h}$ of exposure period, the highest mortality of 76.66 per cent was caused by $H$. indica followed by $S$. glaseri which caused a larval mortality of 66.66 per cent @ $5 \times 10^{9} \mathrm{IJ} / \mathrm{ha}$. The lowest mortality of 31.66 per cent was caused by $S$. glaseri @ $1.25 \times 10^{9} \mathrm{IJ} / \mathrm{ha}$. Percentage of damaged leaves with bore holes decreased with increased dosages of nematodes. $H$. indica was more effective than $S$. glaseri. $H$. indica @ $5 \times 10^{9} \mathrm{IJ} / \mathrm{ha}$ recorded the least leaves damage $(29.16 \%)$ which was on par with $S$. glaseri@ $0 \times 10^{9} \mathrm{IJ} / \mathrm{ha}(45.83 \%)$. The highest leaves damage of $83.33 \%$ was observed in untreated control plants.

The pot culture experiment with bhendi revealed that $H$. indica and $S$. glaseri at the dosage range of 1.25 to $5 \times 10^{9}$ caused mortality of $S$. litura ranging from 60.00 to76.66 per cent and 31.66 to 66.66 per cent for both $H$. indica and $S$. glaseri respectively. Highest mortality of the host due to both nematodes was observed at the highest dosage level of $5 \times 10^{9} / \mathrm{IJ} / \mathrm{ha}$. Earlier reports by Narayanan and Gopalakrishnan (1987), Choo et al., (1989) and Sezhian et al., (1996) established the biocontrol potential of $S$. carpocapsae on $S$. litura where increased dosage levels caused high insect mortality.

In the present study, $H$. indica was found to be more effective than $S$. glaseri. This was also reported by Subramanian (2000) whereas $H$. indica caused higher mortality of Liriomyza trifolii than S. glaseri. Divya et al., (2010) reported the bioefficacy of per cent larval mortality of $H$. armigera and S. litura on cotton plant influenced by $H$. indica was significantly more on final instar larvae at $60 \mathrm{~h}$.

In the present study, the least leaves damage was recorded as with $H$. indica and S. glaseri at the highest dosage level of $5 \times$ $10^{9} / \mathrm{IJ} / \mathrm{ha}$. The higher concentration proved to be more efficient in the present research which demonstrated their efficacy also at lower concentrations. S. glaseri caused dosage mortality response against different stage of four lepidopteran insects (Saravanapriya and Subramanian, 2007).

\section{Acknowledgements}

The authors express their gratitude to University Grants Commission, New Delhi for support by providing fellowship during 2013-15 to carry out my research work.

\section{References}

Choo, H.Y., Kaya, H.K., Reed, D.K. 1989. Biological control of onion maggot and tobacco cutworm with insect parasitic nematodes, Steiner nemafeltiae and Heterorhabditis heliothidis. Korean J. Appl. Ento., 27: 185-189.

Divya, K., Sankar, M., Marulasiddesha, K.N. 2010. Efficacy of Entomopathogenic nematode, Heterorhabditis indica against three lepidopteran insect pests. Asian J. Experi. Biol. Sci., 1: 183-188.

Kalia, V., G. Sharma, D.I. Shapiro-Ilan and S. Ganguly. 2014.Biocontrol potential of Steine rnemathermophilum and its symbiont Xenorhabdus indica against Lepidopteran pests: virulence to egg and larval stages. J. Nemat., 46(1): 1826.

Kaya, H.K. and R. Gaugler. 1993. Entomopathogenic nematodes. Annual Rev. Ento., 38: 181-206.

King, A.B.S. 1994. Heliothis/Helicoverpa (Lepidoptera: Noctuidae). In: Insect Pests of cotton Matthews, G.A. and J.P. Tunstall, (Eds.). CAB International, UK, 39-106 pp.

Laznik, Z., Vidrih, M., Trdan, S. 2012. Effect of different fungicides on viability of entomopathogenic nematodes Steiner nemafeltiae (Filipjev), S. carpocapsae 
(Weiser) and Heterorhabditisdownesi (Stock, Griffin and Burnell) (Nematoda: Rhabditida) under laboratory conditions. Chilean of J. Agri. Res., 72: 62-67.

Narayanan, K. and Gopalakrishnan, C. 1987. Effect of entomogenous nematode, Steiner nemafeltiae (Rhabditida: Steinernematidae) to the pupa, pre-pupa and adult of Spodoptera litura (Noctuidae: Lepidoptera). Indian $J$. Nema., 17: 273-276.

Saravanapriya, B. and Subramanian, S. 2007. Pathogenicity of Entomopathogenic nematode to certain foliar insect pests. Annals of Pl. Prote. Sci., 15: 219-222.

Sezhian, N., Sivakumar, C.V., Venugopal, M.S. 1996. Alteration of effectiveness of Steiner nemacarpocapsae Weiser (Steinernematidae: Rhabditida) against Spodoptera litura (F.) (Noctuidae: Lepidoptera) larvae on sunflower by addition of an insect phagostimulant. Indian J. Nema., 26: 77-81.

Subramanian, S. 2000. Studies on the entomopathogenic nematodes, Heterorhabditis indicus (Poinar, Karunakar and David) and Steiner nemaglaseri (Steiner). Dissertation submitted for Ph.D. (Agri.) to the Tamil Nadu Agricultural University, 1-102pp.

Umamaheswari, R., M. Sivakumar and S. Subramanian. 2004. Virulence of native entomopathogenic nematodes to Spodoptera litura (Lepidoptera: Noctuidae). Curr. Nema, 15: 97-100.

\section{How to cite this article:}

Sharmila Radhakrishnan and Subramanian Shanmugam. 2017. Bioefficacy of Entomopathogenic Nematodes against Spodoptera litura (Lepidoptera: Noctuidae) in Bhendi. Int.J.Curr.Microbiol.App.Sci. 6(7): 2314-2319. doi: https://doi.org/10.20546/ijcmas.2017.607.273 